\title{
Investigation of the Tolerability of Oral Stevioside in Brazilian Hyperlipidemic Patients
}

\author{
Gisleine Elisa Cavalcante da Silva ${ }^{1}$, Abdol Hakin Assef ${ }^{2}$, Claudio Cordeiro Albino ${ }^{3}$, Letícia \\ de Araujo Funari Ferri ${ }^{3}$, Gilson Tasin $^{3}$, Mirian Hideko Takahashi ${ }^{3}$, Wilson Eik Filho ${ }^{3}$ and \\ Roberto Barbosa Bazotte ${ }^{1 *}$ \\ ${ }^{1}$ Departamento de Farmácia e Farmacologia; Universidade Estadual de Maringá; Av. Colombo 5790; \\ rbbazotte@uem.br; 87020-900; Maringá - PR - Brasil. ${ }^{2}$ Clínica de Cardiologia de Maringá - CLINICOR; Maringá \\ - PR - Brasil. ${ }^{3}$ Instituto de Endocrinologia de Maringá - IEM; Maringá - PR - Brasil
}

\begin{abstract}
The tolerability of stevioside $(2.75 \mathrm{mg} / \mathrm{kg} /$ day) obtained from leaves of Stevia rebaudiana (Bert) Bertoni (Compositae) was investigated in hyperlipidemic patients. For this purpose a placebo controlled double blind study was performed. The patients were randomized in two groups: the first group received capsules containing placebo and the second group received capsules containing stevioside $(50 \mathrm{mg})$ during 90 days. All capsules were ingested twice daily, i.e., 2 capsules before lunch and 2 capsules before dinner. After the selection of the patients and each 30 days body mass index and laboratory tests (alanine aminotransferase, aspartate aminotransferase, gammaglutamyltransferase, total cholesterol, high density lipoprotein, low density lipoprotein, very low density lipoprotein, triglycerides and glucose) were performed. Stevioside did not show any clinical relevant modification in all parameters investigated. Moreover the patients did not report severe adverse effect. Thus, we can concluded that stevioside, at least in the doses employed in this study was safe.
\end{abstract}

Key words: Stevia rebaudiana (Bert) Bertoni, stevioside, clinical investigation, placebo effect

\section{INTRODUCTION}

Stevia rebaudiana (Bert) Bertoni (SRB) is a perennial native shrub from west of Paraná State (Brazil) and the northeastern of Paraguay. Leaves of SRB have been used by the Guarani Indians as sweetener and this empirical knowledge was passed by oral tradition for many centuries. Today, it is well established that stevioside is the main sweet component in the leaves of SRB (Bondarev et al., 2002). The use of stevioside increased very much in the last few years. However, scientific and medical evaluation supporting the presumed safety requires further investigations (Bazotte et al., 1986; Geuns, 2003). In fact there are only three clinical studies with oral stevioside, but the authors focused the possibility of an antihipertensive (Chan et al., 2000; Hsieh et al., 2003) and antidiabetic (Gregersen et al., 2004) effect.

Since stevioside consumed as sweetener is orally ingested and considering the potential effect in the liver (Kelmer-Bracht et al., 1985; Constantin et al., 1991; Braguini et al., 2003), the possibility of an hepatotoxic effect must be considered. This concern increased after the demonstration that oral stevioside could be absorbed after its degradation to steviol (Gardana et al., 2003; Koyama et al.,

\footnotetext{
${ }^{*}$ Author for correspondence
} 
2003) by intestinal micro flora. Thus, the present study was carried out to verify the tolerability of stevioside consumed, as sweetener in Brazil. Moreover, the hypolipidemic potential was investigated. The decision to investigate the hypolipidemic effect of stevioside was based in previous studies, which demonstrated the possibility of an increased insulin sensitivity and/or glucose tolerance after the treatment with SRB or stevioside (Ueda et al., 1983; Curi et al., 1986; Gregersen et al, 2004; Lailerd et al., 2004).

\section{PATIENTS AND METHODS}

The plant SRB (Compositae) was identified and a voucher specimen was deposited in the herbarium of the State University of Maringá, Paraná, Brazil.

Standardized stevioside was obtained from dried leaves by a method developed by Alvarez and Kusumoto (1987). The method produced a white crystalline water-soluble mixture of stevioside (70\%) and rebaudioside (20\%). The impurity refered mainly to others rebaudiosides (2\%), mucilage and pigments. The technical specification of the stevioside obtained by this method and employed in this study is described in the Table 1 .

Table 1 - Technical specifications of Stevioside.

\begin{tabular}{ll}
\hline Description & White Crystalline water-soluble compound. \\
Chemical name & $19-\mathrm{O}-\beta$-glucopiranosil-13-O[ $\beta$-glucopiranosil $(1,2)-\beta$-glucopiranosil]- \\
& steviol \\
Elemental composition & $\mathrm{C}_{38} \mathrm{H}_{60} \mathrm{O}_{18}$ \\
Molecular weight & 804.88 \\
Assay & \\
$\quad$ Stevioside & $70 \%$ minimal \\
$\quad$ Rebaudioside A & $20 \%$ minimal \\
$\quad$ Rebaudiosides & $2 \%$ maximal \\
$\quad$ Melting Point & $198{ }^{\circ} \mathrm{C}$ \\
$\quad$ Optical rotation & {$[\alpha]_{25, \mathrm{D}}-39.3^{\circ}$} \\
PH & $5.0-7.0$ \\
Humidity & $3 \%($ maximal $)$ \\
Ash & $1 \%($ maximal $)$ \\
Density & 0.390 to $0.420 \mathrm{~g} / \mathrm{ml}$ \\
Heavy metals & Arsenic $(<1.000 \mathrm{ppm})$, lead $(<3.600 \mathrm{ppm})$, mercury $(<0.005 \mathrm{ppm})$, \\
& chromium $(<0.007 \mathrm{ppm})$, cadmium $(<0.300 \mathrm{ppm})$. \\
Nutritional information & Carbohydrates $(90 \%)$, proteins $(0 \%)$, total fat $(0 \%)$, fibres $(0 \%)$ \\
\hline
\end{tabular}

Preliminary criteria for the inclusion in the trial were age (20-70 years) and untreated hyperlipidemia. The criteria for exclusion were hypertension, cardiovascular diseases, medications with interference in the blood levels of lipids, pregnancy or childbearing potential, hepatic or renal dysfunction, malignancies and diabetes mellitus. The absence of diabetes mellitus was confirmed by the values of glycemia at baseline and after the treatment (Table 2). These exclusion criteria and report about adverse effects were revised during the follow-up clinical visit (each 30 days). Eligible patients ( 49 subjects) were men and women with newly diagnosed and untreated hyperlipidemia. All volunteers enrolled for the trial gave written informed consent to participate in the study.
The clinical investigation was performed in agreement with the ethical guidelines of the Declaration of Helsinki and was approved by the human ethics committee of the State University of Maringá under approval number 021/2002COPEP. Afterwards, information about each eligible patient was obtained using a questionnaire, in which the individuals were requested to report about food habits, physical activity and familiar stipend. In addition, they were instructed to maintain their life habits during the clinical investigation. The patients previously selected were submitted to a placebo controlled double blind study. For this purpose, they were randomized in two groups: the first group (24 patients) received capsules containing talcum (placebo group) and the second group (25 patients) 
received capsules containing stevioside 2.75 $\mathrm{mg} / \mathrm{kg} / \mathrm{day}$ (Stevioside group). The capsules were ingested twice a day, i.e., two capsules $(50 \mathrm{mg})$ before lunch and two capsules $(50 \mathrm{mg})$ before dinner. The capsules and flasks (coded package) with placebo or stevioside were indistinguishable by appearance. Daily dose of $2.75 \mathrm{mg} / \mathrm{kg} /$ day represented $50 \%$ of the acceptable daily intake (ADI) of stevioside. During the treatment $(90$ days) six patients were withdrawn (4 from placebo group and 2 from stevioside group). The safety and tolerability of the stevioside were measured by assessing adverse experiences reported by the patient and adverse effects (defined as abnormal changes in the parameters investigated).

To check compliance all patients were instructed to bring the remained capsules at the day of the clinical visit. Furthermore, immediately after arriving, the body mass index (BMI) was evaluated followed by a collection of blood samples. Venous blood were collected from overnight fasted patients for serum determination of glucose, alanine aminotransferase (ALT), aspartate aminotransferase (AST), gammaglutamyltransferase (GGT), total cholesterol, high density lipoprotein (HDL), low density lipoprotein (LDL), very low density lipoprotein (VLDL) and triglycerides. All these parameters were measured using commercially available kits. A computer program was employed to assign patients to receive stevioside or placebo. The computer program permitted to obtain similar baseline values for all parameters. The statistical analyses were performed by ANOVA and 95\% level of confidence was accepted for all comparisons. Results are reported as means \pm standard error of mean.

\section{RESULTS AND DISCUSSION}

Several studies have demonstrated the potential toxicity of aqueous extract from leaves of SRB (Geuns, 2003). However, it was necessary to consider that the leaves contained not only steviol glycosides, but also, other compounds. Since the majority of toxicological effects were obtained from studies where the leaves were employed (Mazzei-Planas and Kuc 1968; Mellis, 1999; Oliveira-Filho et al., 1989), the discussion here, would be restricted to studies where stevioside and steviol glycosides were employed.

Considering that during the study there was no difference between placebo and stevioside group $(p>0.05)$, the data obtained from 30 and 60 days of treatment were not shown. The treatment during 90 days with stevioside $(2.75 \mathrm{mg} / \mathrm{kg} /$ day $)$ did not change the blood levels of AST, ALT and GGT (Table 2). These results contrasted with studies, which demonstrated potential hepatotoxity to stevioside. However, it must be noted that in these studies, stevioside and its glycosides were infused directly in the liver (Constantin et al., 1991) or isolated mitochondria (Kelmer-Bracht et al., 1985; Braguini et al., 2003). In contrast, in this study stevioside was orally administered and despite of the possibity of its absorption by the intestine, as previously suggested by in vitro studies (Koyama et al., 2003; Gardana et al., 2003), the presence of stevioside in the blood (Geuns, 2003) or its hepatic metabolism (Ishii-Iwamoto and Bracht, 1995) were not confirmed.

Table 2 - Effect of stevioside $(2.75 \mathrm{mg} / \mathrm{kg} / \mathrm{day})$ versus placebo on body mass index (BMI) and blood levels of aspartate aminotransferase (AST), alanine aminotransferase (ALT), gamma-glutamyltransferase (GGT) and glucose in hyperlipidemic patients.

\begin{tabular}{lcccc}
\hline & \multicolumn{2}{c}{ Placebo $(\mathbf{n = 2 0})$} & \multicolumn{2}{c}{ Stevioside $(\mathbf{n}=\mathbf{2 3})$} \\
\cline { 2 - 5 } & Baseline & After Treatment & Baseline & After Treatment \\
\hline BMI $\left(\mathrm{kg} / \mathrm{m}^{2}\right)$ & $27.90 \pm 0.90$ & $27.55 \pm 0.88$ & $25.78 \pm 0.99$ & $25.48 \pm 0.97$ \\
AST $(\mathrm{mg} / \mathrm{dL})$ & $18.10 \pm 0.94$ & $16.55 \pm 1.22$ & $20.30 \pm 0.97$ & $17.48 \pm 1.11$ \\
ALT $(\mathrm{mg} / \mathrm{dL})$ & $21.40 \pm 2.28$ & $18.75 \pm 1.80$ & $20.91 \pm 1.93$ & $17.61 \pm 1.88$ \\
GGT $(\mathrm{mg} / \mathrm{dL})$ & $21.45 \pm 4.16$ & $26.30 \pm 5.89$ & $21.52 \pm 3.36$ & $23.83 \pm 3.43$ \\
Glucose $(\mathrm{mg} / \mathrm{dL})$ & $89.40 \pm 2.27$ & $95.80 \pm 2.54$ & $89.61 \pm 2.31$ & $93.74 \pm 1.89$ \\
\hline
\end{tabular}

The data are showed as mean \pm standard error of the mean.. ${ }^{\mathrm{a}} \mathrm{P}<0.05$ if compared Baseline (Day 0) versus After Treatment (Day 90). 
Another interesting result was the decreased blood levels of total cholesterol and LDL $(p<0.05)$ values during the treatment not only with stevoside but also with placebo (Table 3). Thus, in spite of the fact that all patients were instructed to maintain their life habits during the trial, these data were compatible with a modification in the life stile during the study. The modification in the nutritional habits probably was not quantitative since the BMI did not change (Table 2). Taken together, the results suggested that oral stevioside was safe and supported the well-established tolerability during long term uses as sweetener, particularly in Brazil. However, stevioside orally administered did not show hypolipidemic effect.

Table 3 - Effect of stevioside $(2.75 \mathrm{mg} / \mathrm{kg} /$ day $)$ versus placebo on blood levels of total cholesterol, high density lipoprotein (HDL), low density lipoprotein (LDL), very low density lipoprotein (VLDL) and triacylglycerol in hyperlipidemic patients.

\begin{tabular}{lcccc}
\hline & \multicolumn{2}{c}{ Placebo $(\mathbf{n}=\mathbf{2 0})$} & \multicolumn{2}{c}{ Stevioside $(\mathbf{n}=\mathbf{2 3})$} \\
\cline { 2 - 5 } Parameters & Baseline & After Treatment & Baseline & After Treatment \\
\hline Total Cholesterol & $241.10 \pm 4.55$ & $211.95 \pm 3.84^{\mathrm{a}}$ & $240.61 \pm 3.75$ & $215.91 \pm 4.45^{\mathrm{a}}$ \\
HDL & $55.45 \pm 1.96$ & $55.45 \pm 2.36$ & $53.57 \pm 2.00$ & $52.78 \pm 2.20$ \\
LDL & $153.20 \pm 5.41$ & $127.30 \pm 4.30^{\mathrm{a}}$ & $157.00 \pm 4.52$ & $131.96 \pm 4.92^{\mathrm{a}}$ \\
VLDL & $32.45 \pm 3.14$ & $30.20 \pm 3.37$ & $30.04 \pm 2.48$ & $31.17 \pm 4.05$ \\
Triglycerides & $162.35 \pm 15.72$ & $151.50 \pm 16.82$ & $150.22 \pm 12.43$ & $155.74 \pm 20.27$ \\
\hline
\end{tabular}

The data $(\mathrm{mg} / \mathrm{dL})$ are showed as mean \pm standard error of the mean. ${ }^{a} \mathrm{P}<0.05$ if compared Baseline (Day 0) versus After Treatment (Day 90).

\section{ACKNOWLEDGEMENTS}

This work was supported by CNPq (Grant number 400075/2002-0) and Steviafarma that prepared the capsules containing standardized stevioside and placebo.

\section{RESUMO}

A tolerabilidade do esteviosideo $(2.75 \mathrm{mg} / \mathrm{kg} / \mathrm{dia})$ obtido a partir de folhas de Stevia rebaudiana (Bert) Bertoni (Compositae) foi investigada em pacientes hiperlipidêmicos. Para alcançar este objetivo realizamos estudo clínico do tipo duplo cego. Os pacientes foram randomizados em 2 grupos: o primeiro recebeu cápsulas contendo placebo e o segundo recebeu cápsulas contendo esteviosídeo $(50 \mathrm{mg})$. Foram ingeridas duas cápsulas antes do almoço e duas cápsulas antes do jantar durante 90 dias. Após a seleção dos pacientes e a cada 30 dias o índice de massa corpórea e exames laboratoriais (alanina aminotransferase, aspartato aminotransferase, gama-glutamiltransferase, colesterol total, lipoproteína de alta densidade, lipoproteína de baixa densidade, lipoproteína de muito baixa densidade, trigliceridemia e glicemia) foram realizados. O esteviosídeo não acarretou qualquer alteração clinicamente relevante nos parâmetros investigados. Além disso, os pacientes não relataram efeitos adversos severos. Assim, podemos concluir que o esteviosídeo, na dose empregada neste estudo é seguro, embora não apresente efeito hipolipemiante.

\section{REFERENCES}

Alvarez, M. and Kusumoto, I. T. (1987), Análise quantitativa dos glicosídeos edulcorantes da Stevia rebaudiana e dos seus produtos de hidrólise através de cromatografia líquida de alta performance (HPLC). Arq. Biol. Tecnol., 30, 337-348.

Bazotte, R. B.; Lonardoni, M. T. C.; Alvarez, M.; Gaeti, W. P. and Bersani-Amado, C. A. (1986), Determinação da dose letal média (DL 50) do isosteviol em animais de laboratório. Arq. Biol. Tecnol., 29, 711-722.

Bondarev, N.; Reshetnyak, O. and Nosov, A. (2002), Features of development of Stevia rebaudiana shoots cultivated in the roller bioreactor and their production of steviol glycosides. Planta Med., 68, 759-762.

Braguini, W. L.; Gomes, M. A.; Oliveira, B. H.; Carnieri, E. G.; Rocha, M. E. and Oliveira M. B. (2003), Activity of isosteviol lactone on mitochondrial metabolism. Toxicol. Lett., 143, 83-92.

Chan, P.; Tomlinson, B.; Chen, Y. J.; Liu, J. C.; Hsieh, M. H. and Cheng, J. T. (2000), Double-blind placebocontrolled study of the effectiveness and tolerability of oral stevioside in human hypertension. Br. J. Clin. Pharmacol., 50, 215-220. 
Constantin, J.; Ishii-Iwamoto, E. L.; Ferraresi-Filho, O.; Kelmer-Bracht, A. M. and Bracht, A. (1991), Sensitivity of ketogenesis and citric acid cycle to stevioside inhibition of palmitate transport across the cell membrane. Braz. J. Med. Biol. Res., 24, 767-771.

Curi, R.; Alvarez, M.; Bazotte, R. B.; Botion, L. M.; Godoy, J. L. and Bracht, A. (1986), Effect of Stevia rebaudiana on glucose tolerance in normal adult humans. Braz. J. Med. Biol. Res., 19, 771-774.

Gardana, C.; Simonetti, P.; Canzi, E.; Zanchi, R. and Pietta, P. (2003), Metabolism of stevioside and rebaudioside A from Stevia rebaudiana extracts by human microflora. J. Agric. Food Chem., 51, 6618-6622.

Geuns, J. M. (2003), Stevioside. Phytochemistry, 64, 913-921.

Gregersen, S.; Jeppesen, P. B.; Holst, J. J. and Hermansen, K. (2004), Antihyperglycemic effects of stevioside in type 2 diabetic subjects. Metabolism, 53, 73-76.

Hsieh, M. H.; Chan, P.; Sue, Y. M.; Liu, J.C.; Liang, T. H.; Huang, T. Y.; Tomlinson, B.; Chow, M. S.; Kao, P. F. and Chen, Y. J. (2003), Efficacy and tolerability of oral stevioside in patients with mild essential hypertension: a two-year, randomized, placebocontrolled study. Clin. Ther., 25, 2797-2808.

Ishii-Iwamoto, E. L. and Bracht, A. (1995), Stevioside is not metabolized in the isolated perfused rat liver. Res. Commun. Mol. Pathol. Pharmacol., 87, 167-175.

Kelmer-Bracht, A.; Alvarez, M. and Bracht, A. (1985), Effects of Stevia rebaudiana natural products on rat liver mitochondria. Biochem. Pharmacol., 34, 873-882.

Koyama, E.; Sakai, N.; Ohori, Y.; Kitazawa, K.; Izawa, O.; Kakegawa, K.; Fujino, A. and Ui, M. (2003), Absorption and metabolism of glycosidic sweeteners of stevia mixture and their aglycone, steviol, in rats and humans. Food Chem, Toxicol., 41, 875-883.

Lailerd, N.; Saengsirisuwan, V.; Sloniger, J.A.; Toskulkao, C. and Henriksen, E. J. (2004), Effects of stevioside on glucose transport activity in insulinsensitive and insulin-resistant rat skeletal muscle. Metabolism, 53, 101-107.
Mazzei-Planas, G. and Kuc, J. (1968), Contraceptive properties of Stevia rebaudiana. Science, 162, 1007.

Melis, M. S. (1999), Effects of chronic administration of Stevia rebaudiana on fertility in rats. $J$. Ethnopharmacol., 67, 157-161.

Oliveira-Filho, R. M.; Uehara, O. A.; Minetti, C. A. and Valle, L. B. (1989), Chronic administration of aqueous extract of Stevia rebaudiana (Bert.) Bertoni in rats: endocrine effects. Gen. Pharmacol., 20, 187-191.

Ueda, M.; Weffort, R. M. M.; Zubioli, A.; BersaniAmado, C. A.; Bazotte, R. B.; Gaeti, W. P. and Alvarez, M. (1983), Efeito do extrato aquoso da Stevia rebaudiana (Bert) Bertoni sobre o teste de tolerância à glicose em ratos normais adultos. Rev. Unimar, 5, 111-115.

Received: March 31, 2005; Revised: November 08, 2005; Accepted: March 30, 2006. 